\title{
Baifuzi reduces transient ischemic brain damage through an interaction with the STREX domain of $\mathrm{BK}_{\mathrm{Ca}}$ channels
}

\author{
S Chi ${ }^{1,3,7}, \mathrm{~W} \mathrm{Cai}{ }^{2,7}, \mathrm{P} \mathrm{Liu^{3,6,7 }}, \mathrm{Z} \mathrm{Zhang}^{2}, \mathrm{X} \mathrm{Chen}{ }^{4}, \mathrm{~L} \mathrm{Ga0^{5 }}, \mathrm{J} \mathrm{Qi}^{5}, \mathrm{~L} \mathrm{Bi}^{4}, \mathrm{~L} \mathrm{Chen}^{\star, 2}$ and Z Qi, ${ }^{*, 1,3}$
}

Stroke is a long-term disability and one of the leading causes of death. However, no successful therapeutic intervention is available for the majority of stroke patients. In this study, we explored a traditional Chinese medicine Baifuzi (Typhonium giganteum Engl.). We show, at first, that the ethanol extract of Baifuzi exerts neuroprotective effects against brain damage induced by transient global or focal cerebral ischemia in rats and mice. Second, the extract activated large-conductance $\mathrm{Ca}^{2+}$. activated $\mathrm{K}^{+}$channel $\left(\mathrm{BK}_{\mathrm{Ca}}\right)$ channels, and $\mathrm{BK}_{\mathrm{Ca}}$ channel blockade suppressed the neuroprotection of the extract, suggesting that the $\mathrm{BK}_{\mathrm{Ca}}$ is the molecular target of Baifuzi. Third, Baifuzi cerebroside (Baifuzi-CB), purified from its ethanol extract, activated $\mathrm{BK}_{\mathrm{Ca}}$ channels in a manner similar to that of the extract. Fourth, the stress axis hormone-regulated exon (STREX) domain of the $\mathrm{BK}_{\mathrm{Ca}}$ channel directly interacted with Baifuzi-CB, and its deletion suppressed channel activation by Baifuzi-CB. These results indicate that Baifuzi-CB activated the $\mathrm{BK}_{\mathrm{Ca}}$ channel through its direct interaction with the STREX domain of the channel and suggests that Baifuzi-CB merits exploration as a potential therapeutic agent for treating brain ischemia.

Cell Death and Disease (2010) 1, e13; doi:10.1038/cddis.2009.10; published online 21 January 2010

Subject Category: Neuroscience

This is an open-access article distributed under the terms of the Creative Commons Attribution License, which permits distribution and reproduction in any medium, provided the original author and source are credited. This license does not permit commercial exploitation without specific permission.

Stroke is a devastating condition that annually affects 15 million people worldwide, and is the leading cause of adult disability in industrialized countries. ${ }^{1}$ Although there has been progress in our understanding of the pathophysiology of stroke during the past few decades, stroke continues to pose major therapeutic challenges, both to neuroscientists and to clinicians. ${ }^{2}$ For example, a large number of neuroprotective agents have been shown to successfully reduce infarct size in animal models of stroke, but they have failed to demonstrate efficacy in phase III clinical trials in humans. ${ }^{3}$ To date, no successful therapeutic interventions are available for the majority of stroke patients. ${ }^{1,3}$ The intravenous recombinant tissue plasminogen activator (rt-PA) is the only drug therapy available for thrombolytic treatment of stroke in the United States, Canada and Europe. However, the requirement to exclude hemorrhagic stroke and the restriction to use within $3 \mathrm{~h}$ of the onset of symptoms limit rt-PA therapy to only $\sim 2 \%$ of all stroke patients. ${ }^{1}$ Therefore, there is an urgent need for new therapeutic options for the treatment of stroke.

One of the options that might offer fertile ground for modern drug development is traditional medicines, because traditional medicines, such as traditional Chinese medicine (TCM), have long time since documented the effects of many natural products on humans, and extensive human experience can provide some degree of comfort with regard to their safety. ${ }^{4}$ Clinical application of artemisinin, triptolide, celastrol, capsaicin and curcumin has demonstrated the power and promise of turning traditional medicines into modern drugs. One of the most recent examples is veregen, an extract of green tea leaves, which was approved in 2006 by the US Food and Drug Administration as a new drug to treat perianal and genital condyloma. ${ }^{5}$ As a matter of fact, more than half of the pharmaceutical drugs are either natural products or their derivatives. $^{6}$

\footnotetext{
${ }^{1}$ Department of Physiology, Medical College of Xiamen University, 168 Daxue Road, Xiamen, China; ${ }^{2}$ Department of Physiology, Nanjing Medical University, 140 Hanzhong Road, Nanjing, China; ${ }^{3}$ State Key Laboratory of Brain and Cognitive Science, Institute of Biophysics, 15 Datun Road, Beijing, China; ${ }^{4}$ National Laboratory of Biomacromolecules, Institute of Biophysics, 15 Datun Road, Beijing, China; ${ }^{5}$ College of Pharmaceutical Sciences, Zhejiang University, 388 Yuhangtang Road, Hangzhou, China and ${ }^{6}$ Graduate University of Chinese Academy of Sciences, 19A Yuquan Road, Beijing, China

*Corresponding authors: Z Qi, Department of Physiology, Medical College of Xiamen University, 168 Daxue Road, Xiamen 361005 , China. Tel: +86 0592 218 1330; Fax: +86 0592218 2736; E-mail: qizhi@ xmu.edu.cn or L Chen, Department of Physiology, Nanjing Medical University, 140 Hanzhong Road, Nanjing 210029, China. E-mail: lingchen@njmu.edu.cn

${ }^{7}$ These authors contributed equally to this work.

Keywords: Baifuzi; $\mathrm{BK}_{\mathrm{Ca}}$ channel; brain ischemia; cerebroside; traditional Chinese medicine

Abbreviations: 4VO, 4-vessel occlusion; $\mathrm{BK}_{\mathrm{Ca}}$ channel, large-conductance $\mathrm{Ca}^{2+}$-activated $\mathrm{K}^{+}$channel; Baifuzi-CB, Baifuzi cerebroside; $\left[\mathrm{Ca}{ }^{2+}\right]$ i, intracellular free $\mathrm{Ca}^{2+}$ concentration; e-Baifuzi, ethanol extract of Baifuzi; CTX, charybdotoxin; IPI, interpulse interval; MCAO, middle cerebral artery occlusion; $P_{0}$, single channel open probability; PLO, protein lipid overlay; PPF, paired-pulse facilitation; PPR, paired-pulse ratio; SIGD, synaptically induced glial depolarization; STREX, stress axis hormone-regulated exon; TCM, traditional Chinese medicine; TLC, thin layer chromatography

Received 09.10.09; revised 06.11.09; accepted 09.11.09; Edited by G Melino
} 
Dried tubers of the herb Typhonium giganteum Engl. (Chinese name: BaifuzI), as a TCM, has been recorded in Chinese pharmacopeia and used for the treatment of brain stroke for a long time. ${ }^{7}$ However, unlike industrially manufactured pharmacological drugs used in Western medicine, its active components and molecular targets have not been specified. Obviously, identification of its effects on welldefined molecular targets and the subsequent identification of its active component(s) underlying these effects are important for the evaluation of its therapeutic efficacy. Brain ischemia begins with energy depletion, followed by the disruption of ion homeostasis, membrane depolarization, excessive neurotransmitter (glutamate) release and elevation of intracellular calcium, all of which initiate a neurotoxic cascade that results in neurodegeneration and death of ischemic neurons. ${ }^{8,9}$ The large-conductance $\mathrm{Ca}^{2+}$-activated $\mathrm{K}^{+}\left(\mathrm{BK}_{\mathrm{Ca}}\right)$ channels are widely expressed in the brain ${ }^{10}$ and are preferentially located at glutamatergic synaptic terminals. ${ }^{11,12}$ They react to either increases in intracellular $\mathrm{Ca}^{2+}$ or membrane depolarization by increasing $\mathrm{K}^{+}$efflux. Thus, they function as an 'emergency break' to limit $\mathrm{Ca}^{2+}$ influx for regulating synaptic transmission under conditions of enhanced neuronal excitability. ${ }^{13}$ It has been shown that activation of $\mathrm{BK}_{\mathrm{Ca}}$ channels in ischemic cells by $\mathrm{BK}_{\mathrm{Ca}}$ channel openers could minimize neuronal depolarization, limit accumulation of potentially pathological levels of $\mathrm{Ca}^{2+}$ from a number of potential sources, reduce neurotransmitter release and significantly attenuate infarct growth during ischemic stroke in animal models. ${ }^{14,15}$ In addition, blockade of $\mathrm{BK}_{\mathrm{Ca}}$ channels enhanced cell damage in organotypical slice cultures after oxygen and glucose deprivation. ${ }^{16}$ In this study, we show that the ethanol extract of Baifuzi (e-Baifuzi) shows significant neuronal protective activity in the rat and mice model of ischemic stroke. Second, we show that the $\mathrm{BK}_{\mathrm{Ca}}$ channel is the molecular target of the ethanol extract. Third, we identified that Baifuzi cerebroside (Baifuzi-CB) is the active component of Baifuzi in activating the $\mathrm{BK}_{\mathrm{Ca}}$ channel. Finally, we show that the stress axis hormone-regulated exon (STREX) domain of the $\mathrm{BK}_{\mathrm{Ca}}$ channel, a 59-amino-acid splice insertion located in the cytoplasmic side of the channel, is required for the activation of the $\mathrm{BK}_{\mathrm{Ca}}$ channel by Baifuzi-CB, probably due to direct interaction between Baifuzi-CB and the STREX domain.

\section{Results}

\section{e-Baifuzi protects ischemia-induced brain injury}

e-Baifuzi against ischemia-induced neuronal cell death. Transient global ischemia leads to a dramatic loss of neurons in the CA1 region of the hippocampus. ${ }^{17,18}$ Therefore, we examined whether e-Baifuzi has neuroprotective roles in the CA1 region in the rat model of transient global ischemia, which was made by $20 \mathrm{~min} 4-$ vessel occlusion (4VO). In the CA1 region of the ischemic hemisphere, the number of pyramidal neurons on the eighth day post-4VO was $<50 \%$ of the control (2VO rats, $n=8$, $P<0.01$; Figures $1 \mathrm{a}$ and $\mathrm{b})$. Surprisingly, a single injection of e-Baifuzi (5 or $50 \mathrm{mg} / \mathrm{kg}$ ) at $1 \mathrm{~h}$ post-4VO significantly attenuated neuronal loss in a dose-dependent manner (versus vehicle-treated $4 \mathrm{VO}$ rats, $n=8, P<0.01$ ), although no neuroprotective effect was observed at a dosage of $1 \mathrm{mg} /$ $\mathrm{kg}(P>0.05)$. In contrast, the administration of e-Baifuzi at a dosage of $5 \mathrm{mg} / \mathrm{kg}$ did not affect the number of pyramidal neurons in $2 \mathrm{VO}$ rats $(n=8, P>0.05)$. Furthermore, the administration of e-Baifuzi $(5 \mathrm{mg} / \mathrm{kg})$ even at $4-8 \mathrm{~h}$ post-4VO also significantly reduced ischemia-induced neuronal loss (versus vehicle-treated $4 \mathrm{VO}$ rats, $n=8, P<0.01$; Figure 1c), whereas it could not protect neuronal cells when administered at $24 \mathrm{~h}$ post-4VO $(n=8, P>0.05)$. These results suggested that e-Baifuzi could protect the brain from transient global cerebral ischemia and that its therapeutic time window may last up to $8 \mathrm{~h}$ after the onset of ischemia.

e-Baifuzi improves ischemia-induced deficits in spatial memory. Neuronal damage induced by transient global ischemia is accompanied by severe impairments in performance on hippocampally dependent spatial learning tasks. ${ }^{19}$ To investigate whether e-Baifuzi could improve the behavioral disorder induced by transient global cerebral ischemia, we evaluated its effects on the performance of rats in a Morris water maze test. Results showed that rats subjected to $20 \mathrm{~min}$ global cerebral ischemia (4VO) significantly extended the escape latency to the hidden platform compared with $2 \mathrm{VO}$ rats $(n=8, P<0.01$; Figure $1 \mathrm{~d})$, whereas the swimming speed was not detectably different between them (data not shown). In agreement with its neuroprotection, e-Baifuzi $(5 \mathrm{mg} / \mathrm{kg})$ reduced ischemiainduced prolongation of the escape latency when administered between 1 and $8 \mathrm{~h}$ post-4VO (versus vehicletreated $4 \mathrm{VO}$ rats, $n=8, P<0.01)$. In contrast, it did not affect the escape latency of $2 \mathrm{VO}$ rats at a dosage of $5 \mathrm{mg} / \mathrm{kg}(n=8$, $P>0.05)$. Thus, e-Baifuzi could improve spatial memory impairment induced by global cerebral ischemia.

e-Baifuzi reduces MCAO-produced cerebral infarction. To determine the effect of e-Baifuzi against focal cerebral ischemia-induced injury, we used a mouse model of middle cerebral artery occlusion (MCAO) by the intraluminal filament insertion technique. Infarct size was measured at $24 \mathrm{~h}$ of reperfusion as described previously. ${ }^{20}$ As shown in Figure $2 \mathrm{a}$ and $\mathrm{b}$, a single injection of e-Baifuzi $(5 \mathrm{mg} / \mathrm{kg})$ at $1 \mathrm{~h}$ postMCAO remarkably reduced the hemispheric infarct, from $42 \pm 2 \%$ in vehicle (saline)-injected MCAO mice $(n=10)$ to $19 \pm 5 \%$ in e-Baifuzi-injected MCAO mice $(n=11, P<0.01)$, indicating that e-Baifuzi could reduce cerebral infarct induced by focal ischemia-induced damage.

e-Baifuzi protects the brain from ischemic injury
through activation of $\mathrm{BK}_{\mathrm{Ca}}$ channels
e-Baifuzi activates $B K_{\mathrm{Ca}}$ channels. The above study confirmed the protective role of e-Baifuzi in ischemic injury. As $\mathrm{BK}_{\mathrm{Ca}}$ channels have been shown to have an important role in ischemic stroke, ${ }^{14,15}$ we explored whether the $\mathrm{BK}_{\mathrm{Ca}}$ channel is a potential target for the effect of e-Baifuzi. Wholecell configuration was used to investigate the effect of e-Baifuzi on the whole-cell currents of $\mathrm{BK}_{\mathrm{Ca}}$ channels expressed in $\mathrm{CHO}$ cells. All test experiments $(n=28)$ showed an increase in current amplitude with the application of e-Baifuzi. Figure 3a clearly shows increases in whole-cell $\mathrm{BK}_{\mathrm{Ca}}$ channel currents from the same cell in 
a
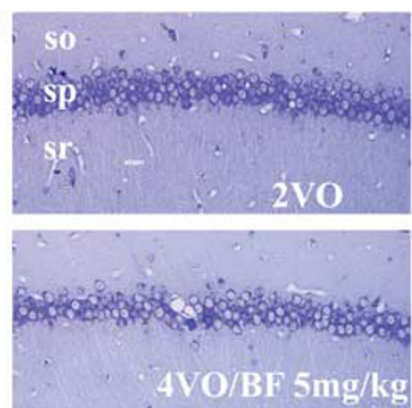
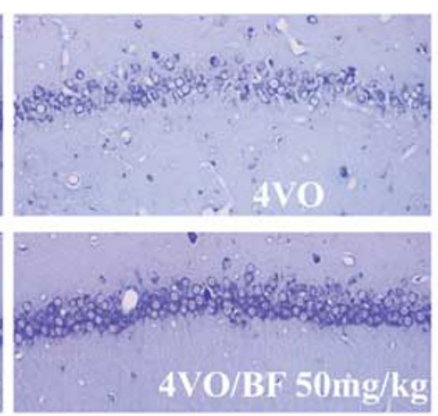
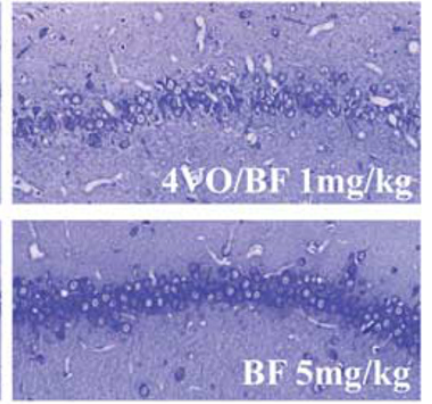

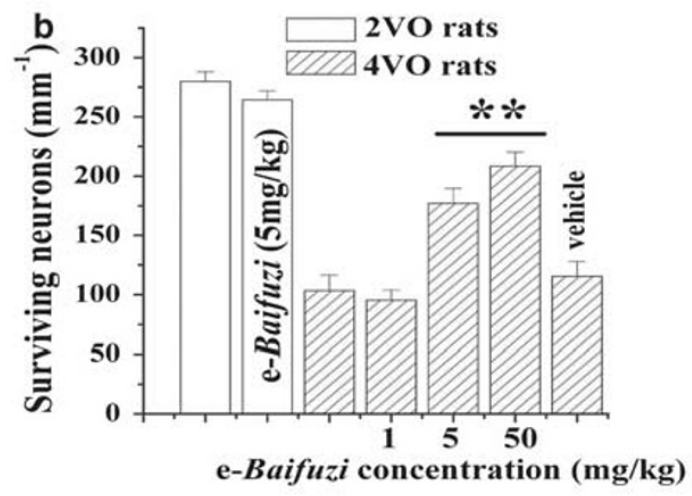

C

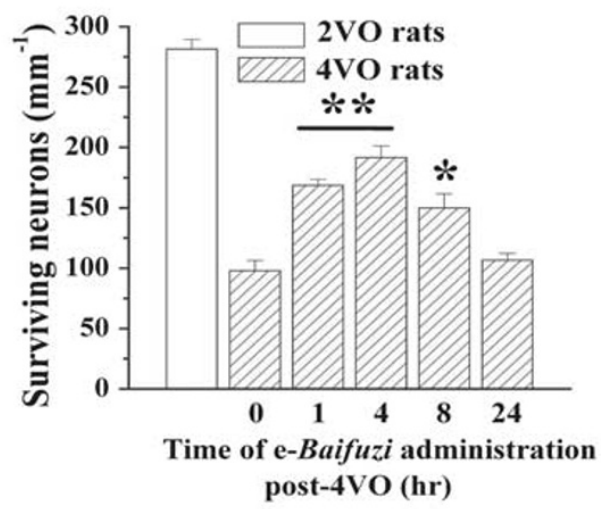

d

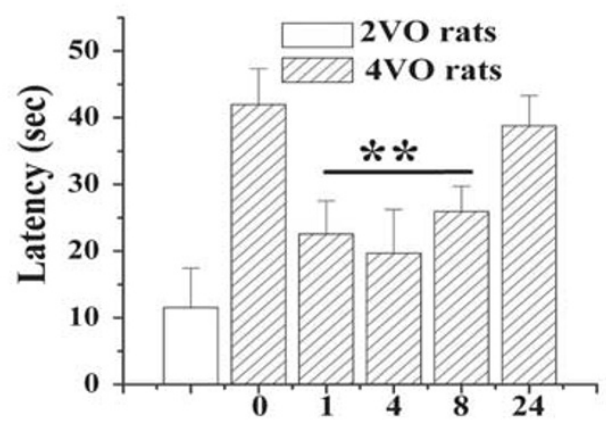

Time of e-Baifuzi administration post-4VO (hr)

Figure 1 Effects of e-Baifuzi on global cerebral ischemia. (a) Representative sections in $2 \mathrm{VO}$ and $4 \mathrm{VO}$ rats treated with vehicle or e-Baifuzi $(0,1,5 \mathrm{and} 50 \mathrm{mg} / \mathrm{kg})$ at $1 \mathrm{~h}$ post-4VO. (b) Bar graphs represent the number of surviving pyramidal neurons of hippocampal CA1 in 2VO (open bars) and 4VO rats (hatched bars). Histological changes in ischemic hippocampal CA1 were assessed on the eighth day post-4VO. (c) Time window of e-Baifuzineuroprotection post-4VO. A single injection (i.p.) of e-Baifuzi (5 mg/kg) is administered at $1,4,8$ or $24 \mathrm{~h}$ post-4VO. ${ }^{*} P<0.05,{ }^{* \star} P<0.01$. (d) Effects of e-Baifuzi on $4 \mathrm{VO}$-impaired special memory. The Morris water maze test was carried out at 3-7 days post-4VO. Bar graphs represent the results of escape latency to reach the hidden platform on the fifth day of Morris water maze training. It must be noted that a single administration of e-Baifuzi within 1-8 h post-4VO decreases the ischemia-induced death of neuronal cells and prolongation of latency. so, stratum oriens; sp, stratum pyramidal; sr, stratum radiatum; BF, e-Baifuzi.

response to e-Baifuzi at a concentration of $0.45 \mu \mathrm{g} / \mu \mathrm{l}$. At a voltage of $+100 \mathrm{mV}, 0.45 \mu \mathrm{g} / \mu \mathrm{l}$ e-Baifuzi increased the current two and threefold at an intracellular $\mathrm{Ca}^{2+}$ concentration of 0.1 and $1 \mu \mathrm{M}$, respectively (Figure $3 \mathrm{~b}$ ). At the single channel level, e-Baifuzi increased the single channel open probability $\left(P_{\mathrm{o}}\right)$ from $2.1 \pm 0.9 \%$ of control $(n=11)$ to $18.4 \pm 6.3 \%$ in the presence of $0.45 \mu \mathrm{g} / \mu \mathrm{l} \mathrm{e-Baifuzi}$ $(n=8)$ without affecting its amplitude (Figure $3 c$ and $d$ ). These results indicated that e-Baifuzi could activate the $\mathrm{BK}_{\mathrm{Ca}}$ channel and implied that the $\mathrm{BK}_{\mathrm{Ca}}$ channel is the molecular target of Baifuzi.
e-Baifuzi reduces presynaptic glutamate release. Excessive glutamate release and subsequent excitotoxicity are major pathological factors leading to neurodegeneration and death of ischemic neurons. ${ }^{8,21}$ Previous studies have reported that $\mathrm{BK}_{\mathrm{Ca}}$ channels located at glutamatergic presynaptic terminals ${ }^{12}$ regulate presynaptic $\mathrm{Ca}^{2+}$ entry, ${ }^{10}$ which in turn regulates presynaptic glutamate release. ${ }^{11}$ Therefore, we investigated the effect of e-Baifuzi on presynaptic glutamate release. First, the excitatory postsynaptic potential (EPSP) slopes in the presence of e-Baifuzi $(0.45 \mu \mathrm{g} / \mu \mathrm{l})$ were consistently less than those in its absence 


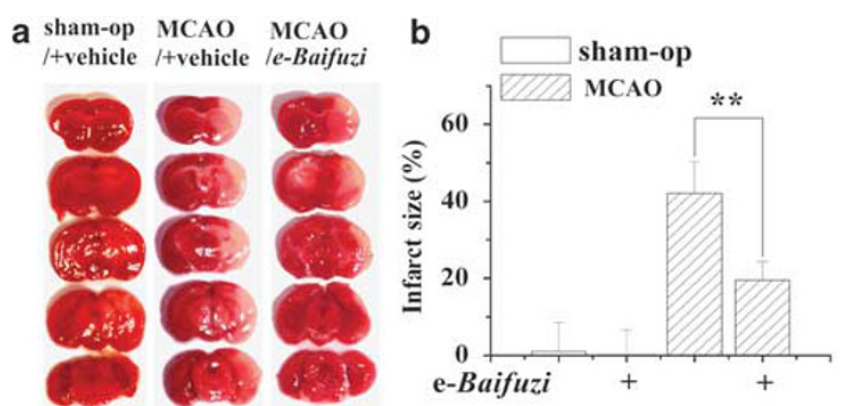

Figure 2 Effects of e-Baifuzi on brain infarct after MCAO. (a) Representative section of vehicle-treated sham, vehicle-treated MCAO and e-Baifuzi $(5 \mathrm{mg} / \mathrm{kg})$ treated MCAO rats. (b) Bar graphs represent the mean infarct volume percentage in sham-op (open bars) and MCAO-mice (hatched bars) treated with vehicel or e-Baifuzi $(5 \mathrm{mg} / \mathrm{kg})$ at $1 \mathrm{~h}$ post-MCAO. ${ }^{* *} P<0.01$ a
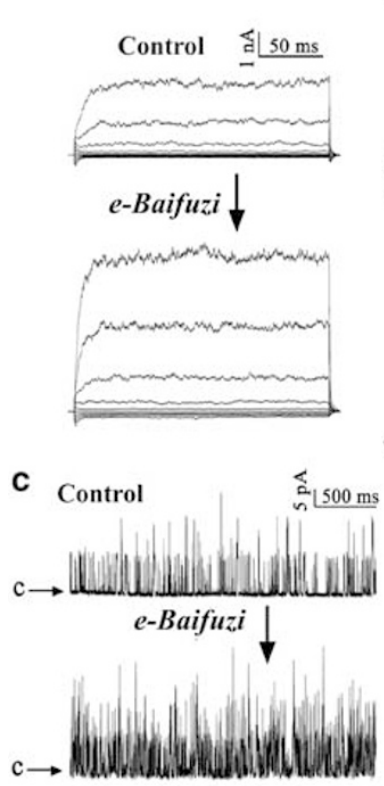

b 3
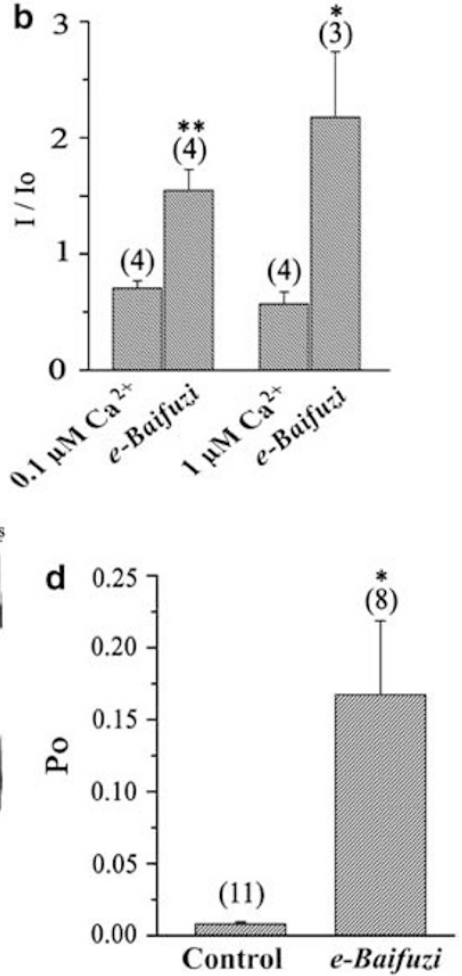

Figure 3 e-Baifuzi activates $\mathrm{BK}_{\mathrm{Ca}}$ channels. (a) Representative current trace of whole-cell $\mathrm{BK}_{\mathrm{Ca}}$ channel current before (control) and after $10 \mathrm{~min}$ of extracellular application of $0.45 \mu \mathrm{g} / \mu \mathrm{l}$ e-Baifuzi. The current was activated by rectangular voltage steps from -80 to $+100 \mathrm{mV}$ for $200 \mathrm{~ms}$ with $10 \mathrm{mV}$ increment. (b) Statistics on ratio values $\left(I / I_{0}\right)$ of the whole-cell $\mathrm{BK}_{\mathrm{Ca}}$ current before $\left(I_{0}\right)$ and after $(I)$ application of $0.45 \mu \mathrm{g} / \mu \mathrm{l}$ e-Baifuzi at $+100 \mathrm{mV}$ in the presence of 0.1 and $1 \mu \mathrm{M}$ intracellular $\mathrm{Ca}^{2+}$, respectively.(c) Representative single channel recordings of the $\mathrm{BK}_{\mathrm{Ca}}$ channels in excised inside-out configuration at $+50 \mathrm{mV}$. Channel openings are shown as an upward deflection. Arrows indicate the level that all the channels are at their closed state. (d) Statistical data for open probability $\left(P_{\mathrm{o}}\right)$ of the single $\mathrm{BK}_{\mathrm{Ca}}$ channels in the presence of $0.45 \mu \mathrm{g} / \mu \mathrm{l}$ e-Baifuzi

(Figure 4a, $\mathrm{P}<0.05 ; n=10$ slices per 5 rats). In addition, the reduction of the EPSP slope completely recovered within 10 min after e-Baifuzi washout $(n=12$ slices per 6 rats; Figure $4 \mathrm{~b}$ ), indicating that e-Baifuzi reversibly suppresses synaptic transmission. Second, paired-pulse facilitation (PPF), a sensitive indicator of presynaptic glutamate release, was measured by delivering two successive stimuli with 25-150 interpulse intervals (IPIs). Compared with that before the addition of e-Baifuzi, the paired-pulse ratio (PPR) at 50-75 IPI was markedly increased after addition of e-Baifuzi $(0.45 \mu \mathrm{g} / \mu \mathrm{l}) \quad(P<0.05, n=15$ slices per 7 rats; Figure 4c). Furthermore, we measured the synaptically induced glial depolarization (SIGD), an indicator of the amount of presynaptic glutamate release, ${ }^{22}$ in the presence of CNQX $(10 \mu \mathrm{M}) / \mathrm{AP5}(50 \mu \mathrm{M})$ (see the 'Materials and Methods' section). Consistent with the result of PPF, the area of SIGD was significantly reduced by perfusion of eBaifuzi $(0.45 \mu \mathrm{g} / \mu \mathrm{l})(P<0.05, n=12$ slices per 6 mice $)$, and could be recovered after the washout of e-Baifuzi (Figure $4 d$ ). Thus, e-Baifuzi could reversibly reduce presynaptic glutamate release, which in turn might protect the brain from the excitotoxicity of excessive glutamate release.

Blockade of $B K_{C a}$ channels abolishes the neuroprotection and glutamate release induced by e-Baifuzi. If the $\mathrm{BK}_{\mathrm{Ca}}$ channel is the molecular target, then its blocker should suppress the neuroprotective effect of e-Baifuzi. To determine whether the neuroprotection of e-Baifuzi is associated with $\mathrm{BK}_{\mathrm{Ca}}$ channel activation, charybdotoxin (CTX, $400 \mathrm{nM}$ ) was administered (i.v.c) for $30 \mathrm{~min}$ before the injection of e-Baifuzi $(5 \mathrm{mg} / \mathrm{kg})$ at $1 \mathrm{~h}$ post-4VO. Blockade of the $\mathrm{BK}_{\mathrm{Ca}}$ channel by CTX pretreatment significantly prevented the neuroprotection of e-Baifuzi (Figure 5a, $P<0.01, n=8$ ), whereas CTX alone had no significant effect on either $2 \mathrm{VO}$ or $4 \mathrm{VO}$ rats in comparison with the corresponding vehicletreated control groups. As CTX is a specific blocker of the $\mathrm{BK}_{\mathrm{Ca}}$ channel, the result strongly suggests that the $\mathrm{BK}_{\mathrm{Ca}}$ channel is the molecular target of e-Baifuzi for its neuroprotective effect. Furthermore, we found that administration of $100 \mathrm{nM} \mathrm{CTX}$ could prevent e-Baifuzi from reducing the area of SIGD $(P<0.05, n=12$ slices per 6 rats; Figure $5 \mathrm{~b}$ ). These results strongly suggest that e-Baifuzi protects ischemia-induced brain injury by opening $\mathrm{BK}_{\mathrm{Ca}}$ channels to decrease presynaptic glutamate release, and gives further evidence that the $\mathrm{BK}_{\mathrm{Ca}}$ channel is the molecular target of Baifuzi.

\section{Baifuzi-CB is the major active ingredient}

The above studies indicated that e-Baifuzi had a significant neuroprotective effect on the ischemic brain through activation of $\mathrm{BK}_{\mathrm{Ca}}$ channels. This result prompted us to seek the active ingredient(s) of Baifuzi. We isolated Baifuzi-CB from e-Baifuzi, ${ }^{23}$ which was verified by ${ }^{1} \mathrm{H}$ and ${ }^{13} \mathrm{C}$ NMR spectra (Supplementary Figures $1 \mathrm{~b}$ and $\mathrm{c}$ ). They appeared as one point on a normal silica gel thin layer chromatography (TLC) plate (Supplementary Figure 1a). Although phytochemical studies have shown that Baifuzi contains several other chemicals, including amino acids, fatty acids, choline, uracil, daucosterol and dipalmin, ${ }^{23}$ we began our studies by focusing on Baifuzi-CB, because our previous study showed that sulfatide, a kind of cerebroside, can potently activate $\mathrm{BK}_{\mathrm{Ca}}$ channels. ${ }^{24}$ In whole-cell patch-clamp recordings, Baifuzi-CB dose-dependently increased $\mathrm{BK}_{\mathrm{Ca}}$ channel currents. Intracellular application of $10 \mu \mathrm{M}$ Baifuzi-CB increased the relative $\mathrm{BK}_{\mathrm{Ca}}$ channel current $\left(I / I_{\mathrm{O}}\right)$ from $0.80 \pm 0.06$ of control to 

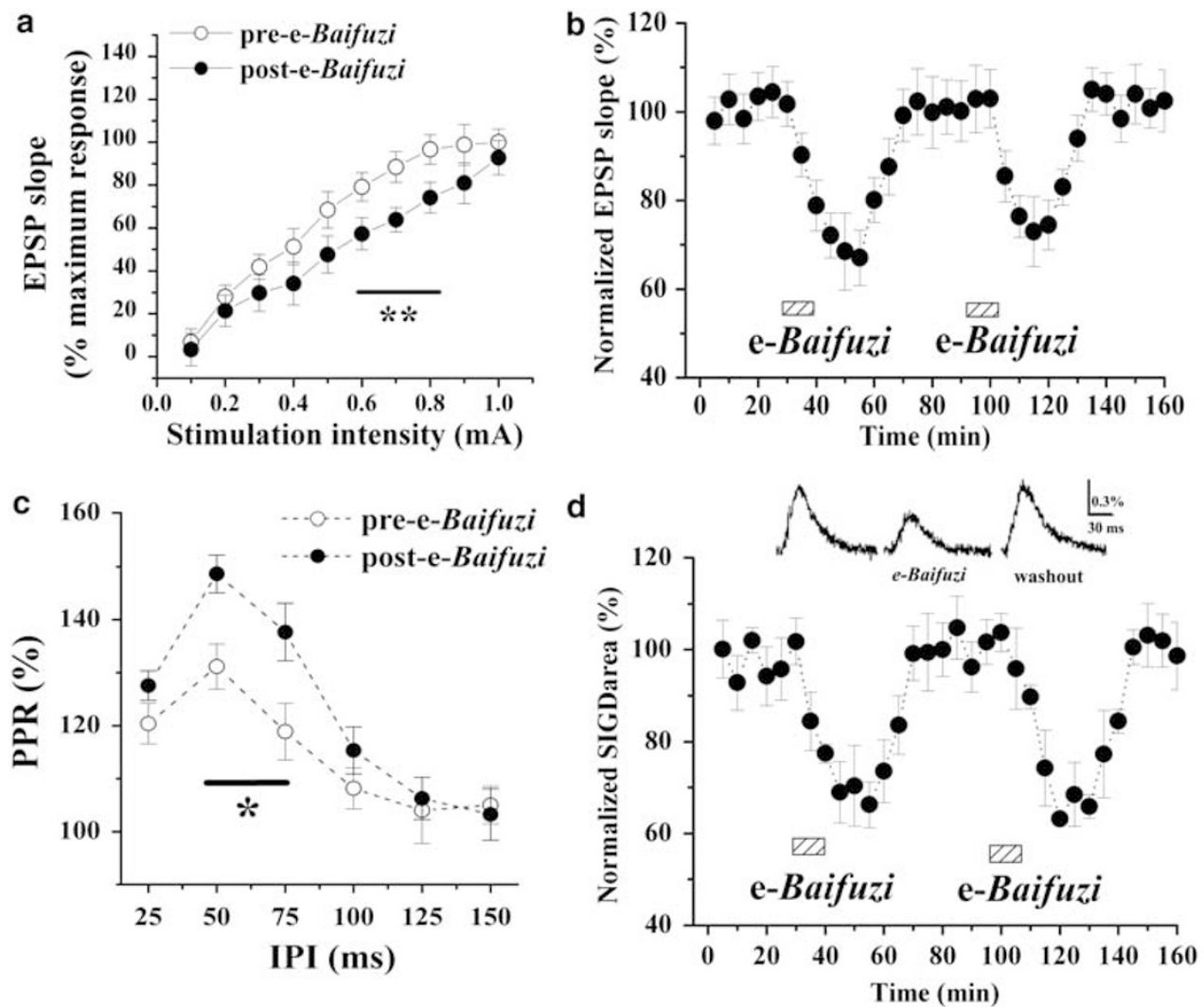

Figure 4 e-Baifuzi reduces presynaptic glutamate release. (a) Stimulus-response curve, in which the EPSP slope were evoked by stimulating the Schaffer collateraleCA1 path with a current from 0.1 to $1.0 \mathrm{~mA}$ in the absence and presence of e-Baifuzi $(0.45 \mu \mathrm{g} / \mu \mathrm{l})$, was constructed by plotting the EPSP slope against stimulus intensity $(0.1-1.0 \mathrm{~mA})$. (b) Reversible inhibition of the EPSP slope by a transient application of e-Baifuzi $(0.45 \mu \mathrm{g} / \mu \mathrm{l})$. Horizontal hatched bar indicates the duration of e-Baifuzi application. (c) Effect of e-Baifuzi on presynaptic glutamate release. Paired-pulses facilitation (PPF) was evoked before and after the addition of e-Baifuzi (0.45 $\mu \mathrm{g} / \mu \mathrm{l})$. Pairedpulses ratios (PPR) are plotted against various IPIs. (d) Sample traces of SIGD were obtained just before, during and after the application of e-Baifuzi (0.45 $\mu \mathrm{g} / \mu \mathrm{l})$. Hippocampal slices were stained with RH155, a voltage-sensitive dye. SIGD: synaptically induced glial depolarization. Horizontal hatched bar indicates the duration of e-Baifuzi application. ${ }^{* *} P<0.01$
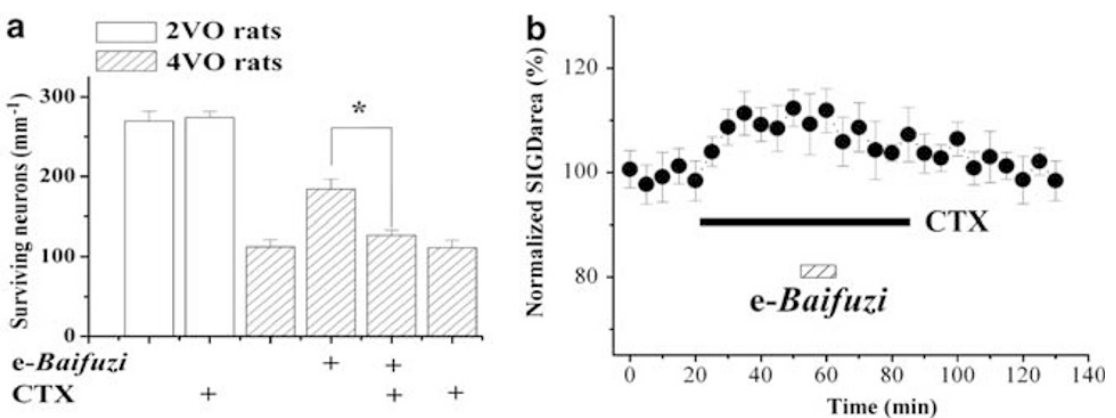

Figure 5 Effect of e-Baifuzi on neuroprotection and glutamate release in the presence of $\mathrm{BK}_{\mathrm{Ca}}$ channel blocker. (a) Role of CTX in e-Baifuzi neuroprotection. CTX at $400 \mathrm{nM}$ was infused into the cereboventricle (i.c.v.) at $30 \mathrm{~min}$ before the injection of e-Baifuzi $(5 \mathrm{mg} / \mathrm{kg})$. Bar graphs represent the number of surviving pyramidal neurons of hippocampal CA1 in 2VO (open bars) and 4VO rats (hatched bars). ${ }^{\star \star} P<0.01$. (b) Effect of e-Baifuzi on the SIGD area in the presence of $100 \mathrm{nM}$ CTX

$3.32 \pm 0.88$ (Figure 6a). On the other hand, extracellular application of $10 \mu \mathrm{M}$ Baifuzi-CB increased the relative $\mathrm{BK}_{\mathrm{Ca}}$ channel current from $0.70 \pm 0.07$ of control to $1.31 \pm 0.15$ (Figure 6b), suggesting that the action site of Baifuzi-CB is easier to access from the intracellular side. To examine whether the activation of $\mathrm{BK}_{\mathrm{Ca}}$ channels by Baifuzi-CB was due to some diffusible intracellular signal molecules, the effect of Baifuzi-CB on $\mathrm{BK}_{\mathrm{Ca}}$ channels was further examined at a single channel level in excised outside-out patches. As shown in Figure 6c, application of $10 \mu \mathrm{M}$ Baifuzi-CB to the outside-out patch enhanced $P_{\mathrm{o}}$ from $3.1 \pm 1.7 \%$ to $12.0 \pm 3.2 \%$. Activation of $\mathrm{BK}_{\mathrm{Ca}}$ channels by Baifuzi-CB in patches excised from the cell membrane strongly suggests that their actions are not mediated by diffusible intracellular signal molecules. On the basis of the amount of Baifuzi-CB purified from e-Baifuzi, it is calculated that e-Baifuzi contains $0.87 \%$ of Baifuzi-CB. Thus, $0.45 \mu \mathrm{g} / \mu \mathrm{l}$ of 
a
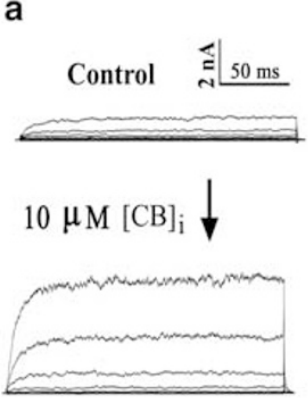

b

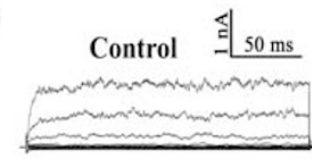

$10 \mu \mathrm{M}[\mathrm{CB}]_{\mathrm{o}}$
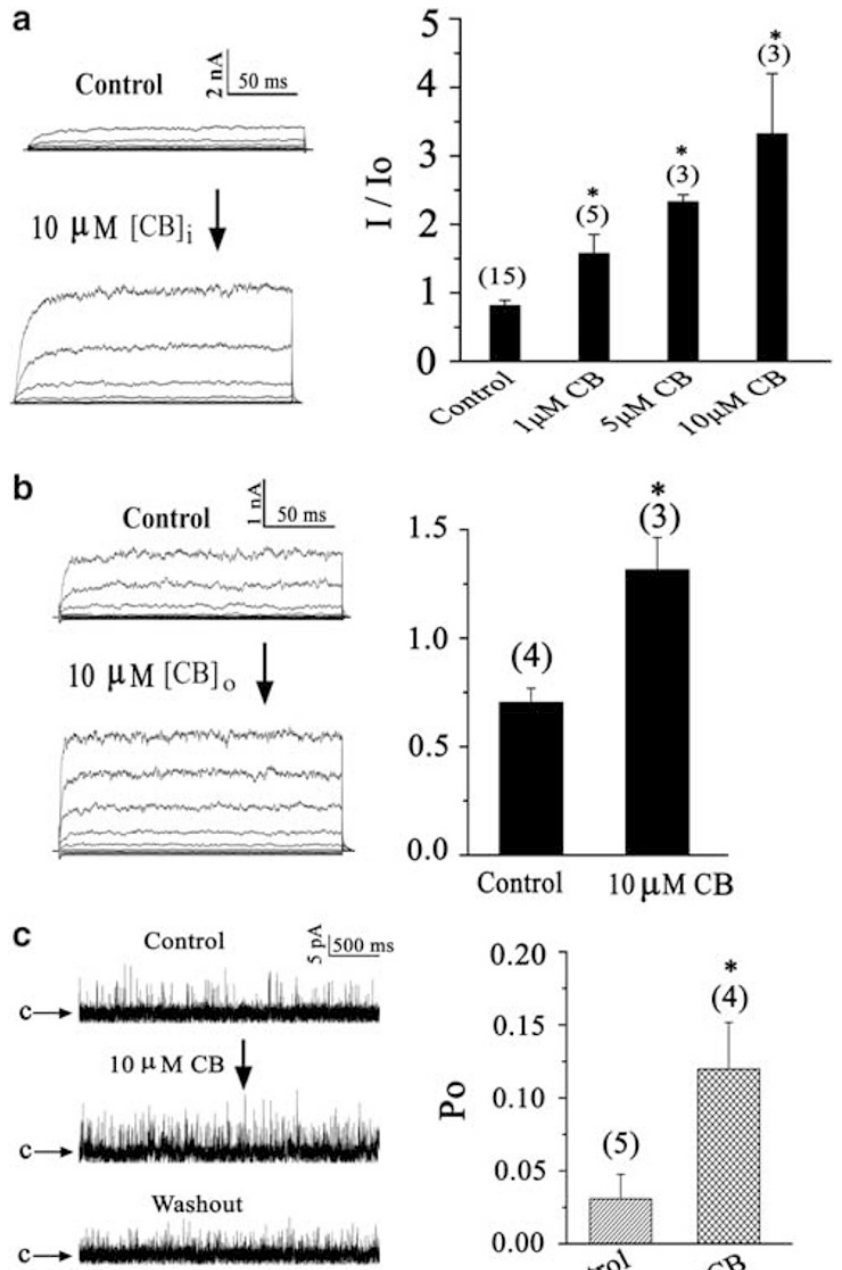

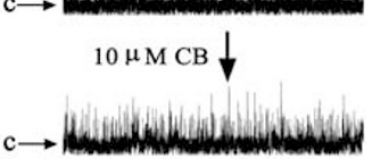

Washout

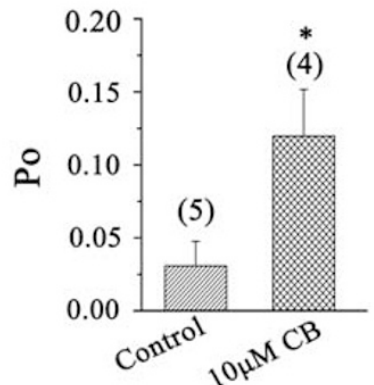

Figure 6 Effect of intracellularly and extracellularly applied Baifuzi-CB on $\mathrm{BK}_{\mathrm{Ca}}$ channels. (a) Left: Representative current traces before (control) and after $10 \mathrm{~min}$ of intracellular application of $1 \mu \mathrm{M}$ Baifuzi-CB ([CB] $\left.]_{\mathrm{j}}\right)$. Right: Statistics on $/ / \mathrm{I}_{\mathrm{o}}$ at different concentrations of Baifuzi-CB at $+100 \mathrm{mV}$. (b) Representative current traces (left) and statistical summary on $I / I_{0}$ (right) for whole-cell $\mathrm{BK}_{\mathrm{Ca}}$ channel current before and after $10 \mathrm{~min}$ of extracellular application of $10 \mu \mathrm{M}$ Baifuzi-CB ([CB] $\left.]_{0}\right)$. (c) Representative single $\mathrm{BK}_{\mathrm{Ca}}$ channel current traces at $+10 \mathrm{mV}$ (left) and statistical summary on its $P_{0}$ (right) with and without Baifuzi-CB in the outside-out configuration. Asterisk indicates significant differences between control and Baifuzi-CB-treated BK $\mathrm{Ca}$ current. ${ }^{*} P<0.05 ; \mathrm{CB}$, Baifuzi-CB
e-Baifuzi corresponds to $5.1 \mu \mathrm{M}$ of Baifuzi-CB (MW $\sim 720$ Dalton). Comparing Figure $3 \mathrm{a}$ and $6 \mathrm{~b}$, the channel activated by $10 \mu \mathrm{M}$ Baifuzi-CB is at the same level as that of $0.45 \mu \mathrm{g} / \mu \mathrm{l} \mathrm{e}$ Baifuzi, indicating that Baifuzi-CB is the major active component responsible for the activation of the $\mathrm{BK}_{\mathrm{Ca}}$ channel.

\section{Molecular mechanism of $\mathrm{BK}_{\mathrm{Ca}}$ channel activation by Baifuzi-CB}

STREX is required for $B K_{C a}$ channel activation by Baifuzi$C B$. It has been shown in our previous studies that STREX is important for activation of $\mathrm{BK}_{\mathrm{Ca}}$ channels by lipid-soluble chemicals. ${ }^{24,25}$ Besides, it has been demonstrated that inclusion of the STREX exon facilitates voltage- and $\mathrm{Ca}^{2+}$ dependent activation of $\mathrm{BK}_{\mathrm{Ca}}$ channels. ${ }^{26}$ To test whether STREX contributes to the activation of the $\mathrm{BK}_{\mathrm{Ca}}$ channel by Baifuzi-CB, we studied its effect on the STREX-deleted mutant of the channel. Both intracellularly $(1 \mu \mathrm{M}$, Figure 7$)$ and extracellularly (10 $\mu \mathrm{M}$, Figure 6b) applied Baifuzi-CB significantly increased whole-cell current for wild-type $\mathrm{BK}_{\mathrm{Ca}}$ channels. The relative whole-cell current was increased from $0.80 \pm 0.06$ of control to $1.57 \pm 0.28$ in the presence of $1 \mu \mathrm{M}$ Baifuzi-CB applied intracellularly (Figure 7b), whereas extracellularly applied Baifuzi-CB (10 $\mu \mathrm{M})$ increased the current from $0.70 \pm 0.06$ of control to $1.31 \pm 0.15$ (Figure 6b). In contrast, the STREX-deleted mutant $\mathrm{BK}_{\mathrm{Ca}}$ channel could not be activated by Baifuzi-CB, whether it was applied intracellularly (Figure 7b) or extracellularly (Supplementary Figure 2), indicating that STREX is required for $\mathrm{BK}_{\mathrm{Ca}}$ channel activation by Baifuzi-CB.

Interaction between Baifuzi-CB and STREX. We investigated the manner in which Baifuzi-CB is sensed by STREX, which is located at the cytoplasmic side, to activate the $\mathrm{BK}_{\mathrm{Ca}}$ channel. A simple explanation may be that STREX interacts directly with Baifuzi-CB and consequently conveys the signal to gate the channel. To test whether the STREX domain is sufficient for Baifuzi-CB binding, we performed a protein lipid overlay (PLO) assay. No interaction was detected between STREX and POPE (1-Palmitoyl-2-Oleoylsn-Glycero-3-Phosphoethanolamine), 1-Palmitoyl-2-Oleoylsn-Glycero-3-[Phospho-rac-(1-glycerol (POPG) or DL- $\alpha$ Phosphatidylcholine Dipalmitoyl (DPPC). In contrast, the STREX domain of the $\mathrm{BK}_{\mathrm{Ca}}$ channel could interact with both

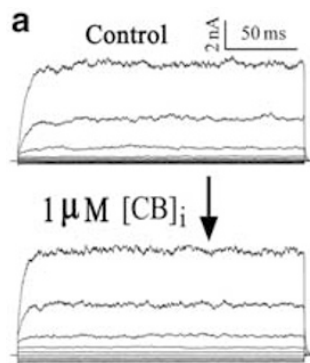

Wild type

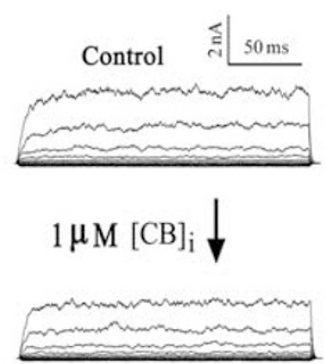

strex deleted

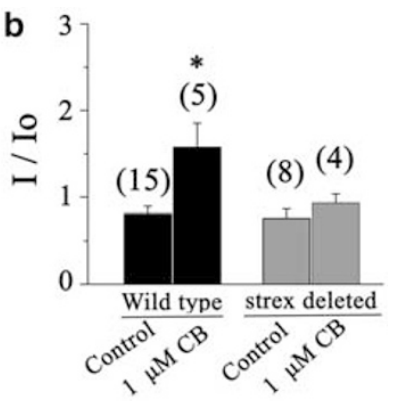

Figure 7 STREX is required for $\mathrm{BK}_{\mathrm{Ca}}$ channel activation by Baifuzi-CB. (a) Representative current traces for wild-type (left) and STREX-deleted (right) BK $\mathrm{Ca}$ channels in control and in the presence of $1 \mu \mathrm{M}$ Baifuzi-CB applied intracellularly ([CB] $)$ ). (b) Statistics on $\| I_{0}$ for wild-type and STREX-deleted BK $\mathrm{Ca}_{\mathrm{Ca}}$ channels at $+100 \mathrm{mV}$. $\mathrm{CB}$, Baifuzi-CB 


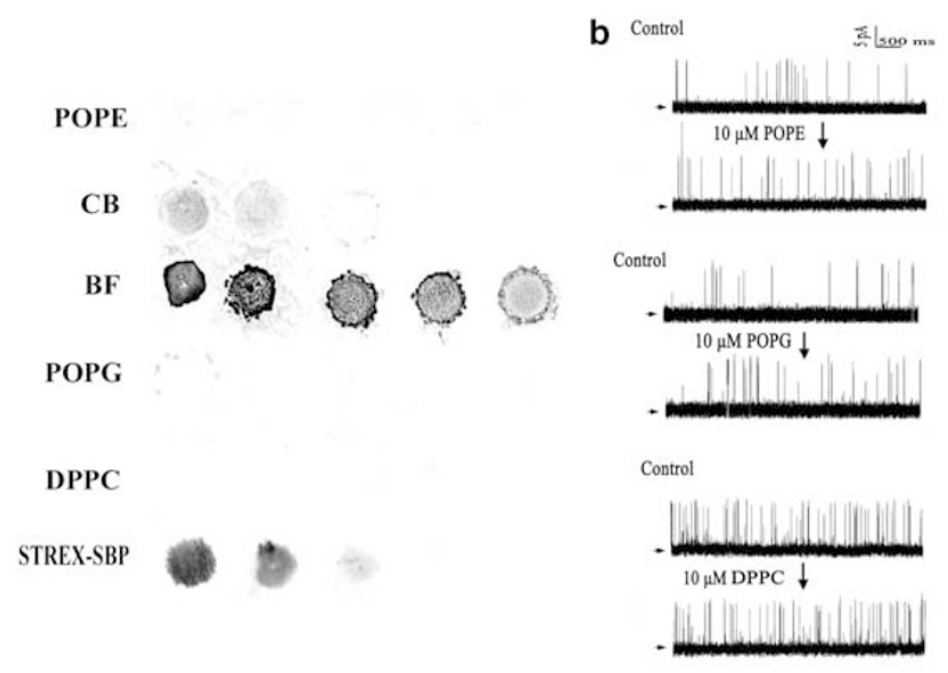

C

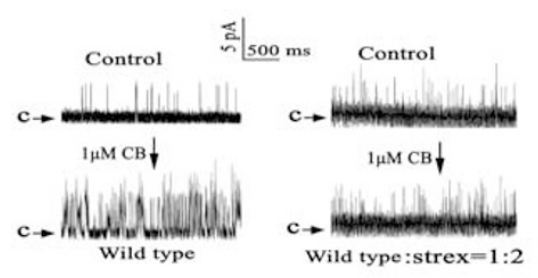

d

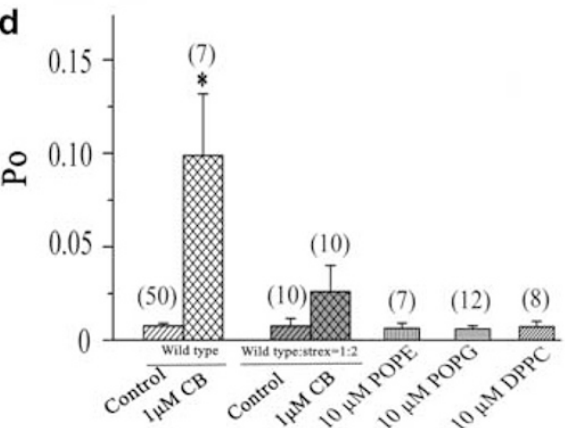

Figure 8 Direct interaction between Baifuzi-CB and the STREX domain of the $\mathrm{BK}_{\mathrm{Ca}}$ channel. (a) The ability of STREX to bind various lipid-soluble materials. The concentration of the lipid-soluble material was increased from right to left and spotted onto nitrocellulose membranes. (b) Effect of POPE, POPG and DPPC on BK $\mathrm{C}_{a}$ channels at $+20 \mathrm{mV}$. (c) Intracellularly applied Baifuzi-CB $(1 \mu \mathrm{M})$ on the single wild-type $\mathrm{BK}_{\mathrm{Ca}}$ channels (left) and on the channels with an overexpression of STREX fragments $\left(\mathrm{BK}_{\mathrm{Ca}} / \mathrm{STREX}=1: 2, \mathrm{q} / \mathrm{q}\right)$ (right) at $+10 \mathrm{mV}$. (d) Statistical summary for the experiment in panels $\mathbf{b}$ and $\mathbf{c}$

e-Baifuzi and Baifuzi-CB in a concentration-dependent manner (Figure 8a), indicating that Baifuzi-CB can bind to the $\mathrm{BK}_{\mathrm{Ca}}$ channel through its STREX domain. Interestingly, Baifuzi-CB and e-Baifuzi, which can bind to STREX, could activate the channel (Figure 3 and Figure 6), whereas POPE, POPG and DPPC, which cannot bind to STREX could not activate the channel (Figures $8 b$ and $d$ ). These results strongly suggest that the interaction with the STREX domain is critical for $\mathrm{BK}_{\mathrm{Ca}}$ channel activation by Baifuzi-CB. If this is true, then the overexpression of STREX fragments will interrupt the interaction between Baifuzi-CB and the STREX domain of the channel, which might subsequently suppress the ability of Baifuzi-CB to activate the channel. To confirm this hypothesis, the STREX fragment was overexpressed with $\mathrm{BK}_{\mathrm{Ca}}$ channels $\left(\mathrm{BK}_{\mathrm{Ca}} / \mathrm{STREX}=1: 2, q / \mathrm{q}\right)$. This overexpression significantly inhibited the ability of Baifuzi$\mathrm{CB}$ to activate the channel (Figure $8 \mathrm{c}$ and $\mathrm{d}$ ). This result further confirmed that the $\mathrm{BK}_{\mathrm{Ca}}$ channel activated by Baifuzi$\mathrm{CB}$ is through its interaction with the STREX domain of the channel.

\section{Discussion}

In this study, we show that e-Baifuzi protects ischemiainduced brain injury through activation of $\mathrm{BK}_{\mathrm{Ca}}$ channels, which in turn could reduce the excitotoxic glutamate release at the condition of brain ischemia. This conclusion is supported by the following four results: (1) e-Baifuzi protected ischemiainduced brain injury in a dose-dependent manner when administered after global or focal cerebral ischemia in rats and mice. (2) e-Baifuzi activated the $\mathrm{BK}_{\mathrm{Ca}}$ channel by increasing its $P_{\mathrm{o}}$ without affecting its amplitude. (3) The neuroprotective effect of e-Baifuzicould be suppressed by the specific blocker of $\mathrm{BK}_{\mathrm{Ca}}$ channels. (4) e-Baifuzi suppressed presynaptic glutamate release through the activation of $\mathrm{BK}_{\mathrm{Ca}}$ channels in hippocampal slices.

Furthermore, we propose that the $\mathrm{BK}_{\mathrm{Ca}}$ channel activated by Baifuzi-CB is through the interaction between Baifuzi-CB and the STREX domain of the $\mathrm{BK}_{\mathrm{Ca}}$ channel according to the following pieces of evidence: (1) PLO assay indicated the direct interaction between Baifuzi-CB and the STREX domain; (2) the STREX domain is required for activation of the $\mathrm{BK}_{\mathrm{Ca}}$ channel by Baifuzi-CB, indicating that the interaction between the STREX domain and Baifuzi-CB is critical for channel activation. This is in accordance with the result that intracellular application of Baifuzi-CB is more effective than that applied extracellularly. (3) Lipid molecules that did not interact with the STREX domain did not activate the $\mathrm{BK}_{\mathrm{Ca}}$ channel. (4) Overexpression of STREX fragments suppresses the ability of Baifuzi-CB to activate the $\mathrm{BK}_{\mathrm{Ca}}$ channel. 
Many $\mathrm{BK}_{\mathrm{Ca}}$ channel modulators have been reported to prevent neuronal degeneration after ischemia in preclinical studies. However, there is no approval of a single $\mathrm{BK}_{\mathrm{Ca}}$ channel modulator for clinical use so far. For example, BMS204352 , one of the potent $\mathrm{BK}_{\mathrm{Ca}}$ channel activators described to prevent neuronal degeneration after ischemia, has failed to improve the clinical outcome in patients affected by stroke. ${ }^{27}$ In this study, we demonstrated that Baifuzi could effectively reduce brain damage in both focal and global ischemia. We are aware that there is no guarantee that Baifuzi will be effective in the clinical treatment of stroke. However, the following reasons may suggest its potential of being regarded as a therapeutic agent: (1) Baifuzi has been effectively used for the treatment of brain stroke for a long time in China ${ }^{7}$. (2) Cerebrosides are rich in the brain, implying that Baifuzi-CB may have a target-specific effect on neurons. (3) As an analog of membrane cerebroside, Baifuzi-CB may be transported by the endogenous transport machinery to target cells to fulfill its action.

Lipid-protein interactions are of fundamental importance, as they partly determine the structures of integral membrane proteins and their activities. ${ }^{28}$ Lipid regulation of channels has been demonstrated for NMDA receptor channels, ${ }^{29,30}$ TRAAK channels, ${ }^{31}$ transient receptor potential channels, ${ }^{32}$ inward rectifier $\mathrm{K}^{+}$channels, ${ }^{33} \mathrm{Ca}^{2+}$ channels, ${ }^{34}$ voltage-dependent $\mathrm{K}^{+}$channels, ${ }^{35} \mathrm{BK}_{\mathrm{Ca}}$ channels ${ }^{36,37}$ and Twik-related $\mathrm{K}^{+}$ channels. ${ }^{38}$ The KcsA potassium channel only opens if the membrane contains a small amount of an anionic lipid, and lipid association has actually been resolved in the crystal structure of $\mathrm{KcsA} \mathrm{K} \mathrm{K}^{+}$channels. ${ }^{39}$ Therefore, it is not surprising that Baifuzi-CB can activate $\mathrm{BK}_{\mathrm{Ca}}$ channels. In agreement with this result, we have previously found that sulfatide, a kind of cerebroside, can potently activate $\mathrm{BK}_{\mathrm{Ca}}$ channels. ${ }^{24}$ In this study, we found that the $\mathrm{BK}_{\mathrm{Ca}}$ channel can be activated by Baifuzi-CB even at the excised membrane, implying that channel activation was not due to some intracellular diffusible signals. Besides, Baifuzi-CB could not increase at the intracellular $\mathrm{Ca}^{2+}$ level in hippocampal neurons (data not shown), suggesting that $\mathrm{BK}_{\mathrm{Ca}}$ channel activation is not due to an increase in intracellular $\mathrm{Ca}^{2+}$ concentration. Then, how does Baifuzi-CB activate the channel? There are at least three possibilities, which are not exclusive with each other: (1) The STREX domain of the $\mathrm{BK}_{\mathrm{Ca}}$ channel is attracted toward the plasma membrane because of the direct interaction with Baifuzi-CB, leading to a stabilization of the open state. This is similar to what has been proposed for the $\mathrm{PI}(4,5) \mathrm{P}_{2}$-dependent gating of inward-rectifier $\mathrm{K}^{+}$channels. $^{40}$ (2) Baifuzi-CB alters the thickness of the membrane, and thus makes the $\mathrm{BK}_{\mathrm{Ca}}$ channel easy to open. This mechanism has been shown for $\mathrm{BK}_{\mathrm{Ca}}$ channel activation by phosphatidylcholines (PCs) of varying chain lengths. ${ }^{41}$ (3) Baifuzi-CB may create stress in the membrane because of its large head group, as we reported previously for the $\mathrm{BK}_{\mathrm{Ca}}$ channel activated by membrane stress created with amphipaths. ${ }^{25}$ Obviously, further studies are required to judge which one or their combinations is correct.

In both global and focal ischemia, restriction of blood flow to the brain limits the delivery of oxygen and glucose to neurons, causing energy depletion. This is followed by a cascade of neurochemical events, including disruption of ion homeostasis, excessive release of glutamate, overload of intracellular $\mathrm{Ca}^{2+}$, release of free radicals, inflammatory changes and finally cell death of neurons, glia and endothelial cells. ${ }^{9,42}$ These injury cascades are interconnected in complex ways, as one event in the cascade can cause or can be caused by multiple other events, and cells suffering from different severity levels of ischemia may undergo different chemical processes. On the other hand, AKT has been shown to have a prominent part in signaling networks that result in the modulation of cellular proliferation, apoptosis and survival. Recently, activation of AKT has been demonstrated to be important in neuronal survival after cerebral ischemia. ${ }^{43-46}$ The neuroprotective effects of nerve growth factor, osteopontin, erythropoietin, as well as preconditioning and postconditioning to reduce ischemia-induced brain injury, are mediated by AKT ${ }^{47-50}$. In our study, we demonstrated that Baifuzi could activate the $\mathrm{BK}_{\mathrm{Ca}}$ channel and reduce the release of glutamate, which is responsible for the neuroprotective effect of Baifuzi. Therefore, it would be very interesting to study whether the AKT pathway is involved in the effect of Baifuzi on brain ischemia.

In summary, we demonstrated that e-Baifuzi provided significant neuroprotection, not only in protecting neurons against cell death but also in promoting behavioral recovery in the animal model of stroke. We identified the $\mathrm{BK}_{\mathrm{Ca}}$ channel as a molecular target for the therapeutic action of Baifuzi, and that Baifuzi-CB is the active component that effectively activates $\mathrm{BK}_{\mathrm{Ca}}$ channels. Through $\mathrm{BK}_{\mathrm{Ca}}$ channel activation, e-Baifuzi limited glutamate release, which is involved in excitotoxicity during ischemic damage. These data provide evidence that e-Baifuzi attenuates ischemia-induced neuronal damage by enhancing the activation of $\mathrm{BK}_{\mathrm{Ca}}$ channels. Its neuronal protective effect provides pharmacological rationale for the traditional use of Baifuzi in stroke. As the natural source of Baifuzi, the medicinal tubers of T. giganteum Engl., has a long history in Chinese traditional medicine, it is hoped that Baifuzi-CB will be a well tolerated, promising therapeutic candidate for the treatment of ischemic brain stroke and other forms of neuronal damage.

\section{Materials and Methods}

Extraction and isolation. Tubers of Baifuzi were collected from Yuxian County (Henan Province, China). The dried material was powdered and then extracted with $95 \%$ ethanol for several days with shaking. The extract was concentrated to yield e-Baifuzi. e-Baifuzi was chromatographed on silica gel, then on ODS to afford Baifuzi-CB, which was confirmed to be a mixture of cerebrosides on the basis of ${ }^{1} \mathrm{H}$ and ${ }^{13} \mathrm{C}$ NMR spectra (Supplementary Figure $1 \mathrm{~b}$ and $\mathrm{C}$ ). TLC experiment indicated that Baifuzi-CB is one of the major spots of e-Baifuzi (Supplementary Figure 1a). The detailed process was described in our previous paper. $^{23}$

Experimental animals. Male Sprague-Dawley rats (weighing 200-250 g, Oriental Bio Service Inc., Nanjing, China) and male mice (weighing $25-30 \mathrm{~g}$, Oriental Bio Service Inc.) were used throughout the study. Animals were housed in a light-controlled room under a $12 \mathrm{~h}$ light-dark cycle starting at 0700 hours and kept at $25^{\circ} \mathrm{C}$. They were given unrestricted access to food and water. All procedures were in accordance with the guidelines of the Institute for Laboratory Animal Research of the Nanjing Medical University.

Preparation of the global brain ischemia model. We used a $4 \mathrm{VO}$ method for transient global ischemia as described elsewhere. ${ }^{51}$ Briefly, using sodium pentobarbital anesthesia $(60 \mathrm{mg} / \mathrm{kg}$, intraperitoneally (i.p.)), both common 
carotid arteries (CCAs) of rats were dissected free, and the incision was closed. Immediately after this procedure, both vertebral arteries (VAs) between the first and second cervical vertebrae were exposed and electro-cauterized completely using a bipolar cauterizer under an operating microscope (SZH-ILLB, Olympus, Tokyo, Japan). After $24 \mathrm{~h}$, the common arteries were occluded with aneurysm clips for $20 \mathrm{~min}$. The clips were then removed, and blood flow though the arteries was confirmed before the wound was sutured. Rectal temperature was continually monitored and maintained at $\sim 37^{\circ} \mathrm{C}$ using a heating pad until the animal had fully recovered from anesthesia. Sham operation (control) groups had a permanent bilateral occlusion of VAs (2VO rats) that was carried out in the same manner as in $4 \mathrm{VO}$ rats, except that the CCAs were not occluded. All rats were allowed to survive for 8 days after the onset of cerebral ischemia.

Preparation of the focal cerebral ischemia model. Focal cerebral ischemia was induced by MCAO for 60 min using the intraluminal filament insertion technique, as described previously. ${ }^{52}$ All mice were anesthetized with $2 \%$ halothane, and were then maintained with $1 \%$ halothane in $70 \% \mathrm{~N}_{2} \mathrm{O}$ and $30 \%$ $\mathrm{O}_{2}$ using a vaporizer. Briefly, a poly-L-lysine ( $0.1 \%$ per weight volume)-coated nylon monofilament thread ( $3 / 0 \mathrm{G}$ with the tip heat blunted to a diameter of $0.104 \mathrm{~mm}$ ) was inserted through the external carotid artery and advanced into the internal carotid artery to occlude the origin of the MCA $(\sim 12 \mathrm{~mm})$. Adequacy of vascular occlusion and reperfusion was monitored in the front parietal cortex of the occluded side by Perimed PF5050 (Perimed, Jarfalla, Sweden) multichannel laser Doppler flowmetry. Body and head temperatures were monitored and controlled at $37 \pm 0.5^{\circ} \mathrm{C}$ using a homeothermic blanket and water pads. Arterial blood pressure and gases were monitored through a femoral catheter. After $60 \mathrm{~min}$ of occlusion, the filament was withdrawn to allow for reperfusion, and animals recovered from anesthesia and survived for $24 \mathrm{~h}$. Sham-operated animals were treated identically, except that MCAs were not occluded after the neck incision.

Drug administration. Animals subjected to cerebral ischemia treatment or sham operation were blinded to drug-treated groups. e-Baifuzi was diluted in $0.9 \%$ saline to a final concentration of $1.0 \%$ ethanol that was used as vehicle control. CTX a $\mathrm{BK}_{\mathrm{Ca}}$ channel blocker, was dissolved in $0.9 \%$ saline and injected into the cereboventricle (i.c.v.). e-Baifuzi was administered i.p. For i.c.v. implantation, mice were anesthetized with ketamine $(80 \mathrm{mg} / \mathrm{kg}$ i.p.). A guide cannula $(4 \mathrm{~mm}$ length, $23 \mathrm{G}$ ) aimed above the left lateral ventricle was implanted and anchored to the skull with four stainless steel screws and dental cement. The guide cannula was implanted above the rostral ventricle so as to not lesion the hippocampus. The drug was prepared freshly on the day of the experiment and injected using a steppermotorized microsyringe (Stoelting, Wood Dale, IL, USA) at a rate of $0.5 \mu / \mathrm{min}$ (final volume $=3 \mu$ l per mouse). Control mice were given an equal volume of vehicle.

Histological examination after 4VO. On the eighth day post-4VO, all animals were deeply anesthetized with pentobarbital $(50 \mathrm{mg} / \mathrm{kg})$ and were perfused transcardially with ice-cold phosphate-buffered saline (PBS), followed by $4 \%$ icecold phosphate-buffered paraformaldehyde. The brains were removed, postfixed in the same fixative for $24 \mathrm{~h}$ and then processed for paraffin embedding. Coronal sections ( $4 \mu \mathrm{m}$ in thickness) including the dorsal hippocampus were cut and stained with toluidine blue. All slide preparations were randomly coded so that observers were blind to the experimental condition. Healthy CA1 pyramidal neurons, showing a round cell body with a plainly stained nucleus, were counted by eye using a conventional light microscope (PD70) with a $100 \times$ objective. The number of surviving pyramidal neurons per $1 \mathrm{~mm}$ length along the extent of the CA1 pyramidal layer was counted as neuronal density (cells per $\mathrm{mm}$ ) as described elsewhere. ${ }^{53} \mathrm{We}$ also conducted supplemental examinations on several slices stained with trypan blue that stains dead cells, and obtained results that were essentially the same as that determined by eye with the toluidine blue-stained slices. To exclude the possibility that alterations in cell density value might be a consequence of changes in the volume of reference, we used a subset of the sections for volume estimation of CA1 stratum radiatum using Scion Image software (Scion Corp., Frederick, MD, USA). Six slices were prepared from the right and left dorsal hippocampus each to count the number of surviving pyramidal neurons.

Lesion size measurement after MCAO. Using 2,3,5-triphenyltetrazolium chloride (TTC) staining, we measured the infarct size at $24 \mathrm{~h}$ of reperfusion, as described previously. ${ }^{20}$ All animals were killed under deep halothane anesthesia, and the brains were quickly frozen and sliced into thick sections for infarct measurement. Tissue infarction was identified by TTC staining in thick $(2 \mathrm{~mm})$ coronal sections. Slices were photographed, and images were studied using imageanalysis software (MCID; Imaging Research, St. Catharines, ON, Canada). The infarct volume in all slices was expressed as a percentage of the contralateral hemisphere after correcting for edema.

Behavioral analysis. Animals were trained in the standard Morris water maze task ${ }^{54}$. For the Morris water maze task, a pool (90 cm diameter, $45 \mathrm{~cm}$ height) made of black-colored plastic was prepared, and was filled with water $\left(20 \pm 1^{\circ} \mathrm{C}\right)$ that was rendered opaque with nontoxic blue paint. Swimming paths were analyzed by a computer system using a video camera (AXIS-90 Target/2; Neuroscience, Inc., Tokyo, Japan). In the hidden-platform test, the platform $(7 \mathrm{~cm}$ in diameter) was submerged $1 \mathrm{~cm}$ below the water surface. The first day of training began with a free swim, in which the swim speed was assessed in the absence of the platform, and then immediately after the free swim, mice were given four training trials per day over 5 days, in which they were given $90 \mathrm{~s}$ to swim to the hidden platform. If a mouse did not find the platform in the allotted time, it was placed on the platform for $15 \mathrm{~s}$. The average swim speed $(\mathrm{cm} / \mathrm{s})$ and latency $(\mathrm{s})$ to reach the platform were scored on all trials and analyzed. Data were obtained from groups of 10 mice throughout the experiments.

\section{Electrophysiological analysis}

Slice preparation. Rats were decapitated under deep anesthesia with ethyl ether. Brains were rapidly removed and coronal brain slices $(400 \mu \mathrm{m})$ were cut using a vibrating microtome (Microslicer DTK 1500, Dousaka EM Co., Kyoto, Japan) in ice-cold cutting solution composed of (in $\mathrm{mM}$ ) 94 sucrose, $30 \mathrm{NaCl}, 4.5 \mathrm{KCl}, 1.0$ $\mathrm{MgCl}_{2}, 26 \mathrm{NaHCO}_{3}, 1.2 \mathrm{NaH}_{2} \mathrm{PO}_{4}$, and $10 \mathrm{D}$-glucose with pH 7.4. The hippocampal slices were continuously incubated in artificial cerebrospinal fluid (ACSF) at $36 \pm 1^{\circ} \mathrm{C}$ for more than $60 \mathrm{~min}$ to allow the slices to recover. ACSF was composed of (in mM) $124 \mathrm{NaCl}, 2 \mathrm{CaCl}_{2}, 4.5 \mathrm{KCl}, 1 \mathrm{MgCl}_{2}, 26 \mathrm{NaHCO}_{3}, 1.2 \mathrm{NaH}_{2} \mathrm{PO}_{4}$, and 10 D-glucose. pH was adjusted to 7.4. Both the cutting solution and ACSF were oxygenated with a gas mixture of $95 \% \mathrm{O}_{2}$ and $5 \% \mathrm{CO}_{2}$.

Field potential recording. For recordings, the slice was transferred into a recording chamber and perfused continuously with oxygenated ACSF at a flow rate of $\sim 1 \mathrm{ml} / \mathrm{min}$. The experiments were conducted at $30 \pm 1^{\circ} \mathrm{C}$. Briefly, orthodromic stimuli were delivered using an electrically polished bipolar tungsten electrode that was placed in the outer third of the molecular stratum of hippocampal dentate gyrus to stimulate the lateral perforant path. Constant current pulses $(0.05 \mathrm{~Hz})$ were supplied by a stimulator (SEN-3301, Nihon Kohden, Tokyo, Japan). EPSP was recorded from the middle third of the molecular stratum with a 4-5 $\mathrm{M} \Omega$ resistance glass microelectrode that was filled with $0.9 \% \mathrm{NaCl}$ and connected to a neutralized, high input-impedance preamplifier with a high-pass filter at $5 \mathrm{kHz}$. The level of test stimulus was set to evoke $\sim 50 \%$ of a minimum stimulus intensity that evoked a saturated EPSP in each slice to avoid possible deprivation of readily releasable transmitters. Signals were amplified using a differential AC amplifier (A-M Systems, model 1700, Seattle, WA, USA). EPSPs were digitized and saved using the pCLAMP system (Axon Instrument Inc., Foster City, CA, USA). Stability of baseline recordings was established by delivering single pulses (1 per min, $0.1 \mathrm{~ms}$ pulse width at an intensity yielding half-maximal EPSP amplitude for a given slice) for 1530 min before collection of input/output functions. Baseline synaptic transmission was assessed by averaging the response to five pulses (from 0.1 to $1.0 \mathrm{~mA}$ ) delivered at a rate of $0.05 \mathrm{~Hz}$. PPF was examined at a range of IPIs $(25-150 \mathrm{~ms})$ and a stimulus intensity of half-maximal for elicitation of EPSP.

Optical recordings. All slices used in optical recording were stained with a voltage-sensitive dye (RH155 $0.2 \mathrm{mg} / \mathrm{ml}$, Nippon Kanko Shikiso Kenkyujo, Okayama, Japan) for $15 \mathrm{~min}$, and were kept in a chamber containing oxygenated ACSF for at least $30 \mathrm{~min}$ for recovery as described previously. ${ }^{55}$ The slices were then transferred into a recording chamber and placed on the stage of an Olympus inverted microscope (IMT-2, Nikon, Tokyo, Japan). Test stimulus was set at 50\% maximal stimulus intensity to evoke optical EPSP (op-EPSP) in each slice. Light from a tungsten-halogen lamp (type JC-24v/200 W, Kondo Philips, Tokyo, Japan) was collimated, and an interference filter with a transmission maximum at $700 \pm 10 \mathrm{~nm}$ (Olympus Optical, Tokyo, Japan) was used. Changes in light absorption associated with membrane potential changes were measured using an optical recording system equipped with a high-speed diode camera with metal oxide (MOS) image sensors $(128 \times 128$ pixels, each of which receives light from a $25 \mu \mathrm{m} \times 25 \mu \mathrm{m}$ sample area) and a data processing unit (HR Deltaron-1700 Fujix; Fuji Photo Film, Tokyo, Japan). To minimize bleaching of the dye molecules and 
photodynamic damages to slices, a heat-absorption filter was placed on the slices, and the light path to the slice was opened only long enough to measure optical responses (1-2s). In each trial, a background image recorded for $16 \mathrm{~ms}$ before electrical stimulation was stored as a reference image. To analyze the change in neuronal activities over time at a given region, data from each pixel were stored and retrieved, and the amplitude of the optical signal (indicated as a percentage change in optical absorbency) was plotted as a function of time. Signals obtained from six pixels in str. molecular were averaged. RH155 dye is reported to stain glial cells preferentially over neuronal cells. ${ }^{56}$ Optical recording with the RH155 dye is used to monitor glial depolarization by the electrogenic glutamate transporter (GLT-1) uptaking the released glutamate. ${ }^{57}$ When AMPA and NMDA receptors are blocked, a delayed depolarizing response can be recorded, which is completely abolished by the specific GLT-1 blocker. Thus, the size of SIGD is considered to reflect the probability of presynaptic glutamate release.

Patch-clamp recordings. Whole-cell currents were measured using a conventional tight seal whole-cell recording technique at room temperature. Pipettes had resistances at a range of $2-5 \mathrm{M} \Omega$ in recording solution containing (in $\mathrm{mM}$ ) $145 \mathrm{KCl}, 10 \mathrm{EGTA}, 10 \mathrm{HEPES}$ ( $\mathrm{pH} 7.3$ with $\mathrm{KOH}$ ) and $\mathrm{CaCl}_{2}$ adjusted to the desired $\left[\mathrm{Ca}^{2+}\right]_{\text {free. }}$ The intracellular free $\mathrm{Ca}^{2+}$ concentration $\left(\left[\mathrm{Ca}^{2+}\right] \mathrm{i}\right)$ was $0.1 \mu \mathrm{M}$, if not stated otherwise. The extracellular solution was Hanks' balanced salt solution (Sigma, St Louis, MO, USA): $1.3 \mathrm{CaCl}_{2}, 0.8 \mathrm{MgSO}_{4}, 5.4 \mathrm{KCl}, 0.4 \mathrm{KH}_{2} \mathrm{PO}_{4}$, $136.9 \mathrm{NaCl}, 0.3 \mathrm{Na}_{2} \mathrm{PO}_{4}, 10 \mathrm{D}$-glucose and $4.2 \mathrm{NaHCO}_{3}$. Compensation for cell capacitance and series resistance was made automatically using EPC-9 or EPC-10 amplifiers; only recordings with stable series resistances $\leqslant 25 \mathrm{M} \Omega$ were included in the study. Currents were amplified using EPC- 9 or EPC-10 patch-clamp amplifiers (HEKA, Lambrecht, Germany), sampled at $2-5 \mathrm{kHz}$ and filtered at $1.5-2.9 \mathrm{kHz}$ using a 4-pole low-pass Bessel filter. Program packages Patchmaster 2.1 and TAC 4.1 (HEKA) were used for data acquisition and analysis. The probability of a single channel being open $\left(P_{0}\right)$ was simply calculated from the total time spent in the open state divided by the total time of recording for the patches containing a single channel. Continuous recordings of 2000-4000 ms were used to estimate $P_{0}$. When multiple channels were present in a patch, $P_{0}$ was calculated from the amplitude histogram as $P_{0}=\left(1-P_{\mathrm{C}}^{1 / M}\right)$, where $P_{\mathrm{C}}$ is the fraction of area under the closed state, and $N$ is the number of channels. To avoid underestimating the number of channels in a patch as less as possible, the number of active single channels in the patch was counted at the condition in which the maximum number of channels was observed. Both e-Baifuzi and Baifuzi-CB activate chick $\mathrm{BK}_{\mathrm{Ca}}$ expressed in $\mathrm{CHO}$ cells, as well as rat $\mathrm{BK}_{\mathrm{Ca}}$ expressed in $\mathrm{HEK} 293$ cells, at both the single channel and whole-cell level. However, for convenience, we present data at the single channel level for chick $\mathrm{BK}_{\mathrm{Ca}}$ and at the whole-cell level for rat $\mathrm{BK}_{\mathrm{Ca}}$ channels. Both e-Baifuzi and Baifuzi-CB have low aqueous solubility and were dissolved in $100 \%$ dimethyl sulfoxide (DMSO) as a stock solution and diluted with intracellular or extracellular solutions to obtain different concentrations as required. The final concentration of DMSO was $<0.5 \%$ per assay, which had no effect on the $\mathrm{BK}_{\mathrm{Ca}}$ channel.

Plasmid construction and STREX-SBP fusion protein purification. The STREX gene of the chick $\mathrm{BK}_{\mathrm{Ca}}$ channel was amplified from pcDNA 3.1-BK $C a$ and subcloned into PQE30( +) (Novagen, Madison, WI, USA). The STREX-SBP (streptavidin-binding peptide) fusion protein was constructed by insertion of a peptide linker (Ser-Gly) between the STREX and SBP tag. After culturing in LB medium containing $0.1 \mathrm{mg} / \mathrm{ml}$ ampicillin at $37^{\circ} \mathrm{C}$ and 200 r.p.m. $/ \mathrm{min}$, cells were induced to express the STREX-SBP fusion protein by adding $0.25 \mathrm{mM}$ IPTG until $\mathrm{OD}_{600}=0.4$. Cells were harvested by centrifugation at 8000 r.p.m. $/ \mathrm{min}$ for $10 \mathrm{~min}$, ultrasonicated and centrifuged at $12000 \mathrm{r.p.m} . / \mathrm{min}$ for $30 \mathrm{~min}$ at $4^{\circ} \mathrm{C}$ to remove the cell fragments. The supernatant was applied to a Ni2 + -NTA column (Amersham Life Sciences, Buckinghamshire, UK). Gradient imidazole was then used to elute the protein. Its purity was analyzed by SDS-PAGE. The purified protein was stored in buffer containing $50 \mathrm{mM}$ Tris- $\mathrm{HCl}, \mathrm{pH} 8.2,200 \mathrm{mM} \mathrm{NaCl}, 1 \mathrm{mM}$ 1,4-dithiothreitol (DTT) and $20 \%$ glycerol at $-70^{\circ} \mathrm{C}$ until use.

PLO assay. Five types of lipid-soluble chemicals, including e-Baifuzi, BaifuziCB, POPE (Avanti, Alabama, USA), POPG (sodium salt, Avanti) and DPPC (Sigma) were diluted and spotted on a Hybond-C extra nitrocellulose membrane (Amersham Life Sciences) with concentration increased from right to left and air-dried for $1 \mathrm{~h}$ at room temperature as described previously. ${ }^{58}$ Lipid spots were blocked in buffer 1 (fatty acid-free BSA buffer $40 \mathrm{mg} / \mathrm{ml}, 25 \mathrm{mM}$ Tris- $\mathrm{HCl} \mathrm{pH} \mathrm{7.9,150} \mathrm{mM} \mathrm{NaCl}$ ) with gentle shaking for $2 \mathrm{~h}$ at room temperature and incubated overnight with $9.2 \mu \mathrm{M}$ STREX-SBP fusion protein in buffer 2 (fatty acid-free BSA $10 \mathrm{mg} / \mathrm{ml}, 25 \mathrm{mM}$ Tris-
$\mathrm{HCl} \mathrm{pH} \mathrm{7.9,150} \mathrm{mM} \mathrm{NaCl}$ ) at $4^{\circ} \mathrm{C}$. Taken as a positive control, the purified STREXSBP fusion protein was also incubated with lipid spots. The membrane was washed in PBS buffer ( $137 \mathrm{mM} \mathrm{NaCl}, 2.7 \mathrm{mM} \mathrm{KCl}, 10 \mathrm{mM} \mathrm{Na} 2 \mathrm{HPO}_{4}, 2 \mathrm{mM} \mathrm{NaH}_{2} \mathrm{PO}_{4}$, $\mathrm{PH} 7.4$ ) with $0.05 \%$ Tween20, and then incubated in a $1: 3000$ dilution of streptavidin-alkaline phosphatase (Promega, Co., Madison, WI, USA) for $1 \mathrm{~h}$. The enzyme was bound to the membrane through interaction between streptavidin and the SBP tag. The protein bound to the lipids was detected with a mixture of 5-bromo4-chloro-3-indolyl phosphate and nitroblue tetrazolium (BCIP/NBT, Ameresco, Solon, $\mathrm{OH}, \mathrm{USA}$ ) as a color development substrate.

Data analysis/statistics. Data were retrieved and processed with the software Micro cal Origin 6.1 (OriginLab, Northhampton, MA, USA). Group data were expressed as means $\pm S$.E. Experimental results were compared among groups by ANOVA, followed by Bonferroni's post hoc test. Statistical analysis was performed using State7 software (STATA Corporation, TX, USA). Differences at $P<0.05$ were considered to be statistically significant.

\section{Conflict of interest}

Professors M Francesca Cordeiro, Frederick W Fitzke and Stephen E Moss are named inventors on a patent application covering the technology disclosed in this report.

Acknowledgements. We thank Professor D Armstrong (Laboratory of Neurobiology, NIEHS) for the gift of the rat $\mathrm{BK}_{\mathrm{Ca}}$ channel gene. We thank Ms MY Huang for technical assistance. This study was supported by NSFC (30470447 to ZQ; 30872725 to LC), 973 program (2005CB522804 and 2006CB911003 to ZQ; 2009 CB941701 to LC) and PCSIRT (IRT0631 to LC). SC and PL contributed toward data collection and analysis for patch-clamp studies; PL and LB contributed toward PLO analysis; WC and ZZ contributed toward data collection and analysis for the animal model of stroke; XC, LG and JQ contributed toward purification and identification of Baifuzi-CB; LC and ZQ contributed toward experimental design, data analysis and manuscript writing.

1. Shuaib A, Hussain MS. The past and future of neuroprotection in cerebral ischaemic stroke. Eur Neurol 2008; 59: 4-14.

2. Donnan GA, Fisher M, Macleod M, Davis SM. Stroke. Lancet 2008; 371: 1612-1623.

3. Gladstone DJ, Black SE, Hakim AM. Toward wisdom from failure: lessons from neuroprotective stroke trials and new therapeutic directions. Stroke 2002; 33: 2123-2136.

4. Corson TW, Crews CM. Molecular understanding and modern application of traditional medicines: triumphs and trials. Cell 2007; 130: 769-774.

5. Chen ST, Dou J, Temple R, Agarwal R, Wu KM, Walker S. New therapies from old medicines. Nat Biotechnol 2008; 26: 1077-1083.

6. Koehn FE, Carter GT. The evolving role of natural products in drug discovery. Nat Rev Drug Discov 2005; 4: 206-220.

7. Sucher NJ. Insights from molecular investigations of traditional Chinese herbal stroke medicines: implications for neuroprotective epilepsy therapy. Epilepsy Behav 2006; 8: 350-362.

8. Hansen AJ, Nedergaard M. Brain ion homeostasis in cerebral ischemia. Neurochem Pathol 1988; 9: 195-209.

9. Dirnagl U, ladecola C, Moskowitz MA. Pathobiology of ischaemic stroke: an integrated view. Trends Neurosci 1999; 22: 391-397.

10. Knaus HG, Schwarzer C, Koch RO, Eberhart A, Kaczorowski G, Glossmann $\mathrm{H}$ et al. Distribution of high-conductance $\mathrm{Ca}^{2+}$-activated $\mathrm{K}^{+}$channels in rat brain: targeting to axons and nerve terminals. J Neurosci 1996; 16: 955-963.

11. Hu H, Shao LR, Chavoshy S, Gu N, Trieb M, Behrens R et al. Presynaptic $\mathrm{Ca}^{2+}$-activated $\mathrm{K}^{+}$channels in glutamatergic hippocampal terminals and their role in spike repolarization and regulation of transmitter release. J Neurosci 2001; 21: 9585-9597.

12. Sailer CA, Kaufmann WA, Kogler M, Chen L, Sausbier U, Ottersen OP et al. Immunolocalization of BK channels in hippocampal pyramidal neurons. Eur $\mathrm{J}$ Neurosci 2006; 24: 442-454.

13. Ghatta S, Nimmagadda D, Xu X, O'rourke ST. Large conductance, calcium-activated potassium channels: structural and functional implications. Pharmacol Ther 2006; 110: 103-116.

14. Gribkoff VK, Starrett Jr JE, Dworetzky SI, Hewawasam P, Boissard CG, Cook DA et al. Targeting acute ischemic stroke with a calcium-sensitive opener of maxi-K potassium channels. Nat Med 2001; 7: 471-477.

15. Hong KW, Lee JH, Kim KY, Park SY, Lee WS. Cilostazol: therapeutic potential against focal cerebral ischemic damage. Curr Pharm Des 2006; 12: 565-573.

16. Runden-Pran E, Haug FM, Storm JF, Ottersen OP. BK channel activity determines the extent of cell degeneration after oxygen and glucose deprivation: a study in organotypical hippocampal slice cultures. Neuroscience 2002; 112: 277-288. 
17. Zola-Morgan S, Squire LR, Rempel NL, Clower RP, Amaral DG. Enduring memory impairment in monkeys after ischemic damage to the hippocampus. J Neurosci 1992; 12 2582-2596.

18. Pulsinelli WA, Brierley JB, Plum F. Temporal profile of neuronal damage in a model of transient forebrain ischemia. Ann Neurol 1982; 11: 491-498.

19. Block F, Schwarz M. Global ischemic neuronal damage relates to behavioural deficits: a pharmacological approach. Neuroscience 1998; 82: 791-803.

20. Alkayed NJ, Goto S, Sugo N, Joh HD, Klaus J, Crain BJ et al. Estrogen and Bcl-2: gene induction and effect of transgene in experimental stroke. J Neurosci 2001; 21: 7543-7550.

21. Leker RR, Shohami E. Cerebral ischemia and trauma: different etiologies yet simila mechanisms: neuroprotective opportunities. Brain Res 2002; 39: 55-73.

22. Chen L, Dai XN, Sokabe M. Chronic administration of dehydroepiandrosterone sulfate (DHEAS) primes for facilitated induction of long-term potentiation via sigma 1 (sigma1) receptor: optical imaging study in rat hippocampal slices. Neuropharmacol 2006; 50: 380-392.

23. Chen XS, Chen DH, Si JY, Tu GZ. Chemical constituents of Typhonium giganteum Engl. $J$ Asian Nat Prod Res 2001; 3: 277-283.

24. Chi S, Qi Z. Regulatory effect of sulphatides on BK $\mathrm{C}_{\mathrm{C}}$ channels. Br J Pharmacol 2006; 149 1031-1038.

25. Qi Z, Chi S, Su X, Naruse K, Sokabe M. Activation of a mechanosensitive BK channel by membrane stress created with amphipaths. Mol Membr Biol 2005; 22: 519-527.

26. Erxleben C, Everhart AL, Romeo C, Florance H, Bauer MB, Alcorta DA et al. Interacting effects of $\mathrm{N}$-terminal variation and strex exon splicing on slo potassium channel regulation by calcium, phosphorylation, and oxidation. J Biol Chem 2002; 277: 27045-22752.

27. Nardi A, Olesen SP. BK channel modulators: a comprehensive overview. Curr Med Chem 2008; 15: 1126-1146.

28. White $\mathrm{SH}$, Ladokhin AS, Jayasinghe S, Hristova K. How membranes shape protein structure. J Biol Chem 2001; 276: 32395-32398.

29. Miller B, Sarantis M, Traynelis SF, Attwell D. Potentiation of NMDA receptor currents by arachidonic acid. Nature 1992; 355: 722-725.

30. Petrou S, Ordway RW, Singer JJ, Walsh Jr JV. A putative fatty acid-binding domain of the NMDA receptor. Trends Biochem Sci 1993; 18: 41-42.

31. Maingret F, Patel AJ, Lesage F, Lazdunski M, Honore E. Lysophospholipids open the two pore domain mechano-gated $\mathrm{K}^{+}$channels TREK-1 and TRAAK. J Biol Chem 2000; 275 10128-10133.

32. Nilius B, Owsianik G, Voets T. Transient receptor potential channels mee phosphoinositides. EMBO J 2008; 27: 2809-2816.

33. Huang $\mathrm{CL}$, Feng $\mathrm{S}$, Hilgemann DW. Direct activation of inward rectifier potassium channels by PIP2 and its stabilization by G $\beta$. Nature 1998; 391: 803-806.

34. Delmas P, Coste B, Gamper N, Shapiro MS. Phosphoinositide lipid second messengers: new paradigms for calcium channel modulation. Neuron 2005; 47: 179-182.

35. Schmidt D, Mackinnon R. Voltage-dependent $\mathrm{K}^{+}$channel gating voltage sensor toxin sensitivity depend on the mechanical state of the lipid membrane. Proc Natl Acad Sci USA 2008; 105: 19276-19281.

36. Kirber MT, Ordway RW, Clapp LH, Walsh Jr JV, Singer JJ. Both membrane stretch and fatty acids directly activate large conductance $\mathrm{Ca}^{2+}$-activated $\mathrm{K}^{+}$channels in vascular smooth muscle cells. FEBS Lett 1992; 297: 24-28.

37. Clarke AL, Petrou S, Walsh Jr JV, Singer JJ. Modulation of $\mathrm{BK}_{\mathrm{Ca}}$ channel activity by fatty acids: structural requirements and mechanism of action. Am J Physiol 2002; 283. C1441-C1453.

38. Honore $\mathrm{E}$. The neuronal background K(2P) channels: focus on TREK1. Nat Rev Neurosci 2007; 8: 251-261.

39. Valiyaveetil $\mathrm{FI}$, Zhou Y, MacKinnon R. Lipids in the structure, folding and function of the KcsA K ${ }^{+}$channel. Biochemistry 2002; 41: 10771-10777.

40. Suh BC, Hille B. PIP2 is a necessary cofactor for ion channel function: how and why? Annu Rev Biophys 2008; 37: 175-195.

41. Yuan C, O'Connell RJ, Jacob RFR, Mason P, Treistmank SN. Regulation of the gating of $\mathrm{BK}_{\mathrm{Ca}}$ channel by lipid bilayer thickness. J Biol Chem 2007; 282: 7276-7286.

42. Doyle KP, Simon RP, Stenzel-Poore MP. Mechanisms of ischemic brain damage. Neuropharmacology 2008; 55: 310-318.

43. Noshita N, Lewen A, Sugawara T, Chan PH. Evidence of phosphorylation of akt and neuronal survival after transient focal cerebral ischemia in mice. J Cereb Blood Flow Metab 2001; 21: 1442-1450.

44. Shibata M, Yamawaki T, Sasaki T, Hattori H, Hamada J, Fukuuchi Y et al. Upregulation of akt phosphorylation at the early stage of middle cerebral artery occlusion in mice. Brain Res 2002; 942: 1-10.

45. Ohba N, Kiryu-Seo S, Maeda M, Muraoka M, Ishii M, Kiyama H. Transgenic mouse overexpressing the Akt reduced the volume of infarct area after middle cerebral artery occlusion. Neurosci Lett 2004; 359: 159-162.

46. Zhao H, Sapolsky RM, Steinberg GK. Phosphoinositide-3-kinase/Akt survival signaling pathways are implicated in neuronal survival after stroke. Mol Neurobiol 2006; 34 249-269.

47. Kilic E, Kilic U, Soliz J, Bassetti CL Gassmann M, Hermann DM. Brain-derived erythropoietin protects from focal cerebral ischemia by dual activation of ERK-1/-2 and Akt pathways. FASEB J 2005; 19: 2026-2028.

48. Saito A, Narasimhan P, Hayashi T, Okuno S, Ferrand-Drake M, Chan PH. Neuroprotective role of a proline-rich Akt substrate in apoptotic neuronal cell death after stroke: relationships with nerve growth factor. J Neurosci 2004; 24: 1584-1593.

49. Meller R, Stevens SL, Minami M, Cameron JA, King S, Rosenzweig $\mathrm{H}$ et al. Neuroprotection by osteopontin in stroke. J Cereb Blood Flow Metab 2005; 25 : 217-225.

50. Pignataro G, Meller R, Inoue K, Ordonez AN, Ashley MD, Xiong Z et al. In vivo and in vitro characterization of a novel neuroprotective strategy for stroke: ischemic postconditioning. $J$ Cereb Blood Flow Metab 2008; 28: 232-241.

51. Li Z, Cui S, Zhang Z, Zhou R, Ge Y, Sokabe M et al. DHEA-neuroprotection -neurotoxicity after transient cerebral ischemia in rats. J Cereb Blood Flow Metab 2009; 29: 287-296.

52. Mulcahy NJ, Ross J, Rothwell NJ, Loddick SA. Delayed administration of interleukin-1 receptor antagonist protects against transient cerebral ischaemia in the rat. BrJ Pharmacol 2003; 140: 471-476.

53. Cai W, Zhu Y, Furuya K, Li Z, Sokabe M, Chen L. Two different molecular mechanisms underlying progesterone neuroprotection against ischemic brain damage. Neuropharmacology 2008; 55: 127-138.

54. Morris RGM. Development of a water maze procedure for studying spatial learning in the rat. J Neurosci Methods 1984; 11: 47-60.

55. Chen L, Sokabe M. Presynaptic modulation of synaptic transmission by pregnenolone sulfate as studied by optical recordings. J Neurophysiol 2005; 94: 4131-4144.

56. Konnerth A, Obaid AL, Salzberg BM. Optical recording of electrical activity from parallel fibres and other cell types in skate cerebellar slices in vitro. J Physiol 1987; 393: 681-702.

57. Kojima S, Nakamura T, Nidaira T, Nakamura K, Ooashi N, Ito E et al. Optical detection of synaptically induced glutamate transport in hippocampal slices. J Neurosci 1999; 19 : 2580-2588.

58. Dowler S, Kular G, Alessi DR. Protein lipid overlay assay. Sci STKE 2002; 2002: PL6.

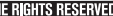

Derivative Works 3.0 License. To view a copy of this license, visit http:// creativecommons.org/licenses/by-nc-nd/3.0/

\section{Supplementary Information accompanies the paper on Cell Death and Disease website (http://www.nature.com/cddis)}

